\section{A World Bibliography of Bibliographies}

TrE need for the making of bibliographies arises from the multiplicity of books, the excessive production of which was a matter for complaint before the invention of printing. Bibliographies, or lists of books, existed before the Christian epoch. Not long after the introduction of printing, the recording of all books made became impossible and the difficulty became one of keeping track of bibliographies. Eventually the ever increasing number of bibliographies of bibliographies has justified the publication of Mr. Josephson's bibliography of bibliographies of bibliographies. To-day the aggregate of existing bibliographies is countless. Thanks to the work of the International Federation for Documentation, an increasing number are produced according to a standard system. Such bibliographies can be amalgamated into a single index, where all references to a particular topic, collected from a variety of sources in different languages, can be found immediately in one place. The great mass, however, are arranged according to a variety of systems, mostly alphabetical, which make amalgamation impossible. The adoption of individual systems gives rise to the need for a work by which to ascertain what bibliographies have been compiled on a given subject, and Mr. T. Besterman is attempting to meet the need by a "World Bibliography of Bibliographies" to contain about 24,000 entries of separately published bibliographies of all countries on all subjects. In addition to printed books, it will cover every sort of written matter as well as the subject classes of Patent Office Abridgements from 1617 until 1930. It is promised in two volumes, the first on October 1, 1939 and tho second early in 1940. Orders should be sent to Mr. T. Besterman, 98 Heath Street, London, N.W.3.

\section{International Federation for Documentation}

THE fifteenth International Conference of the International Federation for Documentation, which is being organized by the Swiss Association for Documentation, will be held at Zurich under the presidency of Dr. Philipp Etter, president of the Swiss Republic, during August 10-13. The International Federation for Documentation, the seat of which is at The Hague, was founded for the purpose of studying all particulars concerning the publication of new information and of developing means whereby it may be made available as required. At the World Congress on International Bibliography two years ago at Paris, the Federation was adopted unanimously by delegates of more than forty Governments as the international authority in such matters. One of the main objects of the Federation is the great work of promoting the subject-indexing of information, since information that has not been catalogued by subject cannot bo found unaided except by accident, by the individual research worker. It can be made available only by systematic and comprehensive indexing. Consequently the Federation endeavours to bring together in direct collaboration all bodies and individuals interested in the mobilization of knowledge.
Axose the methods adopted by the Federation is the promotion of international conferences. Full con. ferences are held biennially in different countries: that held last year at Oxford under the patronage of the British Government and the presidency of Sir William Bragg will be remembered by many. In alternate years smaller conferences, restricted to selected topics, are held. The subjects for discussion at the Zurich Conference comprise : (1) the division of work between librarians and documentalists, (2) documenta. tion in connoxion with administration, (3) documentation in industry and (4) photograplic reproduction methods for documentation purposes. The Conference includes visits and excursions to works and places of interest in the neighbourhood. Everyone concerned with the increase or organization of knowledge should make a point of attending. Special travelling facilities are afforded in connexion with the Swiss National Exhibition. The membership feo is 20 Swiss francs and the papers will bo printed in advance and sold at the price of 10 Swiss francs. The address of the secretary is Herr E. Mathys, Chemins de Fer, Bern, Switzerland.

\section{Zoology in China}

Ir is gratifying to note that the Bulletin of the Fan Memorial Institute of Biology of Peiping (Pekin), now in its eighth volume, has been able to continue publication notwithstanding the disturbed condition of internal affairs prevailing in China. The last issue to hand of the Zoological Series (No. 3, JulyAugust 1938) contains eight articles, all of which are written by Chinese zoologists. The most extensive are S. C. Yu's studies on Chinese Crustacea of the group Caridina and those by Messrs. Hsu and Chow on helminths of the human intestine. The articles are all written in English and havo Chineso summaries.

\section{Royal Commission Science Research Scholarships}

THE Science Scholarships Committee of the Royal Commission for the Exhibition of 1851 announces the following appointments for 1939 . Senior Studentships: On the recommendation of the University of Cambridge: Mrr. S. Devons, for research in nuclear physics at the University of Cambridge; Dr. E. F. Gale, for research in biochemistry at the University of Cambridge; Mr. F. Hoyle, for research in theoretical physics at the University of Cambridge; Dr. W. J. C. Orr, for research in physical chemistry at the University of Cambridge. On the recommendation of the University of Oxford: Dr. F. C. Frank, for research in physical chemistry at the University of Cambridge. Overseas Scholarships: On the recom. mendation of MrGill University, MIontreal : Dr. H. B. Newcombe, for research in genetics and cytology at the John Innes Horticultural Institution, Merton, and the California Institute of Technology, Pasadena; Dr. R. L. McIntosh, for research in physical chemistry at the University of Cambridge. On the recommenda. tion of the University of Toronto : Dr. H. E. Johns, for research in physics at the University of Cambridge. On the recommendation of the University of Sydney : Miss R. H. Harradence, for research in organic 
chemistry at the University of Oxford; J. W. Cornforth, for research in organic chemistry at the University of Oxford. On the recommendation of the University of New Zealand: A. J. C. Nicholson, for research in physical chemistry at the University of Cambridge. On the recommendation of the University of Cape Town : C. B. Coetzee, for research in geology at the University of Cambridge. On the recommendation of the University of Dublin : B. P. Beirne, for research in entomology at the British Iuseum (Natural History), London. On the recom. mendation of Benares Hindu University : Dr. P. B. Mathur, for research in plant physiology at the University of Cambridge.

\section{Announcements}

Prof. L. J. Hendersox, Lawrence professor of chemistry at Harvard University, who is distinguished for his investigations on the physico-chemical structure and organization of the body, has been invited by the Royal Society to deliver the next Pilgrim Trust Lecture which is to be given in London. Prof. Henderson has accepted the invitation. In referring to the Pilgrim Trust Lectures in Nature of July 1, p. 15, it was incorrectly stated that the selection of Sir William Bragg to deliver the second lecture of the series had been in the hands of the Royal Society ; the Royal Society invites American men of science to lecture in England under the scheme, while the National Academy of Sciences invites a representative of science in Great Britain to lecturo in the United States.

$A x$ a meeting held in Paris on June 30 , the president of the Société des Ingénieurs Civils de France, II. Raymond Berr, presented the Gold Medal of the Société (Prix Annuel) to MIr. W. T. Halcrow, for his paper entitled "Tapping a Lake at 32 metres below the Surface" read before the Société in Paris on May 27,1938 . This is the first occasion on which the premier prize medal of the Société has been presented to a British subject since its award was instituted in 1861. Mr. Halcrow, who is the president of the British Section of the Société des Ingénieurs Civils, described in his paper the Ben Nevis tunnel through which water from Loch Treig is delivered to the British Aluminium Company's power station at Fort William.

THE following have been elected honorary members of the Royal Society of Edinburgh: Harvey (Williams) Cushing, emeritus professor of neurology, Yale School of Medicine, Newhaven, Conn.; Otto Loewi, lately professor of pharmacology, University of Graz; Bernard Lyot, of the Observatory, Meudon.

Trie following have been elected to the Physical Mathematical Class of the Prussian Academy of Sciences : Prof. A. Butenandt, director of the Kaiser-Wilhelm Institut für Biochemis in Berlin; Prof. K. Meyer, director of the Institut für Ackerbau und Landbaupolitik, Berlin; Prof. A. Ludin, pro. fessor of hydraulic and agricultural hydraulic engineering, Berlin; Dr. F. Seewald, director of the
Deutsche Versuchsanstalt für Luftfahrt, in Berlin, and Prof. J. Bartels, professor of geophysics, Berlin.

Daye Helen Gwynne-Vaughan, professor of botany in Birkbeck College, London, has been appointed director of the Auxiliary Territorial Service, Army Branch, with rank of Chief Controller, as from July 3.

TuE Council of the Institution of Civil Engineers has approved of the formation of a Railway Engineering Section which will include within its scope all matters appertaining to the study of railway engineering relating to planning, construction, maintenance and research, and including structures, rolling-stock and equipment, the matters akin thereto.

The Council of the Royal Meteorological Society has awarded the Howard Prize (an aneroid barometer), given annually for the best essay on a selected meteorological subject, to Cadet V. A. Mcilillan, of H.M.S. Conway School Ship. Cadet C. D. Thorpe, also of H.M.S. Conway, was placed second in the competition. The subject of the essays was "The Barometer and its Use in Meteorology

TinE International Society for the Investigation of Biorhythms will hold its second conference at Utrecht, Holland, on August 25-26, under the presidency of Dr. E. Forsgren. Dr. H. Holmgren, of the Karolinske Institutet, Stockholm, is the secretary. Further information can be obtained from Dr. Frits Gerritzen, Lunteren, Holland.

THE eleventh Congress of the International Union against Tuberculosis will be held in Berlin on September 16-20 under the presidency of Dr. Otto Walter. The main subjects for discussion will bo: the problem of the virulence of the tubercle bacillus; the value of systematic examinations for the detection of tuberculosis in subjects more than fifteen years of age ; and the rehabilitation of the tuberculous. Further information can bo obtained from the National Association for the Provention of Tuber. culosis, Tavistock Houso North, Tavistock Square, W.C.1.

A JoINT meeting of the Royal Meteorological Society and the American Meteorological Society will bo held in Toronto on the occasion of the meeting of the International Union of Geodesy and Geophysics in Washington early in September. 'The joint meeting will be held during August 28-29, and is being organized by Mr. J. Patterson, controller of the Canadian Meteorological Service. Seminars on radiation and on extra-tropical cyclones will be held. It is also hoped that a Canadian branch of the royal Meteorological Society may be inaugurated at this meeting. Further information can be obtained from Mr. J. Patterson, Meteorological Office, 315 Bloor Street West, Toronto, Ontario, or from the Assistant Secretary of the Royal Moteorological Society, 49 Cromwell Road, South Kensington, London, S.w.7. 